\title{
Effluent Quality Assessment of Selected Wastewater Treatment Plant in Jordan for Irrigation Purposes: Water Quality Index Approach
}

\author{
Mohamad Najib Ibrahim' \\ 1 Department of Civil Engineering, Tafila Technical University, P.O. Box 179, Tafila 66110, Jordan \\ e-mail:m.najib@ttu.edu.jo; ibrahim6@buffalo.edu
}

\begin{abstract}
The use of treated wastewater for irrigation purposes will be an essential component for sustainable water resources management, especially in the water-stressed countries as in Jordan. In this context, an attempt has been made to determine the suitability of effluent quality of selected wastewater treatment plants in Jordan for the irrigation purposes based on weighted arithmetic water quality index (WQI) approach, according to the Jordanian standards for reclaimed domestic wastewater. The effluent wastewater quality records from 22 wastewater treatment plants within a one-year-monitoring period from March 2015 to February 2016 were used. Fifteen physical, chemical, and microbiological parameters were selected to calculate WQI. According to the WQI scale classification, most of the selected wastewater treatment plants were not in full compliance with the Jordanian standards for the reclaimed domestic wastewater regarding the direct reuse of treated wastewater for the irrigation purposes. Therefore, for category A (i.e., vegetables that are normally eaten cooked, parking areas, sides of roads inside cities, and playgrounds), one plant is classified in the 'Excellent water' class and six plants as a "Good water" class. For category $\mathrm{B}$ (i.e., irrigation of fruit trees, green areas, and sides of roads outside the cities), one plant is classified in the 'Excellent water' class and twelve plants as a "Good water" class. For category C (i.e., irrigation of industrial crops, field crops, and forest trees), one plant is classified in the 'Excellent water' class and fifteen plants as a "Good water" class. The effective weight calculations identified that E. coli is considered the most effective parameter in the WQI values in category $\mathrm{A}$, and to a lesser extent, $\mathrm{SAR}, \mathrm{pH}, \mathrm{BOD}$, and $\mathrm{NO}_{3}^{-}$. For category $\mathrm{B}$, the $\mathrm{SAR}, \mathrm{pH}$ and $E$. coli parameters are considered the most effective parameters in the WQI values. In turn, for category $\mathrm{C}$, the SAR, $\mathrm{pH}$, and $\mathrm{PO}_{4}^{-3}$ parameters are considered the most effective parameters in the WQI values. Thus, these parameters based on category are considered as the main parameters which degrade the effluent wastewater quality for irrigation purposes. The results of this study are beneficial for the water managers and policymakers for proper actions on water resources and agricultural management in Jordan.
\end{abstract}

Keywords: water quality index, treated effluent, irrigation water, wastewater reuse, Jordan

\section{INTRODUCTION}

Water quantity and quality have become a dominant concern in developing countries in recent years as is the case in Jordan. The per capita share of renewable water resources is among the lowest worldwide (UN-Water, 2015). The water resources in Jordan are very limited because low average rainfall and high evaporation (i.e., in the year 2017, the rainfall amounted to 8165 million cubic meters (MCM) while the evaporation was 7636 MCM) (MWI, 2017). Additionally, the urban population continues to grow, exacerbated by successive waves of refugees and displaced people. These conditions contribute to enlarging the gap between the available water resources and the water demand for the domestic, agricultural and industrial needs (the estimated water demand quantity for all sectors is $1412 \mathrm{MCM}$ in 2017, while the available water resources quantity is 1053.6 MCM (MWI, 2017)). Thus, the concluded fact is that Jordan is suffering from severe water shortage problems and water has a strategic value.

Currently, the treated wastewater is widely implemented around the world and considered a reliable alternative water source for agricultural 
irrigation, industrial reuse, groundwater recharge, and potable water supply (Jiménez \& Asano, 2008). The reuse of wastewater has been largely applied in agriculture, motivated by its sustainable availability (i.e., constant source of water), decrease of fertilizer use (i.e., wastewater contains many nutrients that can fulfill the nutrients requirement for plant growth) and resolving the problems associated with the wastewater disposal (Candela et al., 2007; Jeong et al., 2014; Lyu et al., 2015).

Part of Jordan's water strategy and policies is to manage wastewater as a vital resource rather than a waste (MWI, 2002). In the year 2017, almost $88 \%$ of the treated wastewater in Jordan was reused in the agriculture sector (144.2 MCM out of $163.68 \mathrm{MCM}$ ) and this water contributed $14 \%$ to the total annual water resources that is 1053.6 MCM (MWI, 2017). Additionally, the treated wastewater covers approximately $26 \%$ of the total irrigation water supply, which is estimated to be 551.8 MCM (MWI, 2017). However, the treated wastewater represents the largest contributor to the anthropogenic pollution. It deteriorates the water quality and the ecological state of receiving water bodies and therefore may pose health risks (Fatta et al., 2004; Shakir et al., 2017); hence, restrict their quality to serve the end-users (i.e., drinking, industrial and agricultural irrigation purposes) leading to prevent social and economic development. Thus, water quality monitoring, assessment, and modeling are necessary for the protection and effective management of water resources (Pesce \& Wunderlin, 2000).

Various approaches to assess the surface water and groundwater quality have been proposed, such as water quality indices (WQIs) and multivariate statistical method (cluster analysis, factor analysis). WQIs are being widely used in the water quality assessment studies and have played an increasingly important role in water resource management (Debels et al., 2005; Sutadian et al., 2016). The WQI was firstly proposed by Horton in 1965 (Horton, 1965) and then modified by Brown and co-workers in 1970 (Brown et al., 1970). Since then, many different methods for calculating the WQIs have been proposed by several authors (Abbasi \& Abbasi, 2012; Lumb et al., 2011; Sutadian et al., 2016). The water quality index indicates the overall quality of water for any intended use by a single dimensionless value. This approach overcomes the traditional water quality assessment approach which compares the individual parameter with guideline permissible limit values without providing a whole picture of water quality (M. Ibrahim, 2018).

Accordingly, it is very important to properly monitor and assess the effluent quality of wastewater treatment plants for sustainable water resources management and safeguarding the public health. Thus, the major objective of the present study was to investigate the suitability of the effluent quality from selected wastewater treatment plants in Jordan for the irrigation purposes based on weighted arithmetic water quality index approach. A secondary objective was to identify the main parameters which may affect the effluent quality in each of the studied wastewater treatment plants (i.e. the effect of each water quality parameter on the WQI values). Special emphasis was placed on the assessment of the physicochemical and microbiological properties of the effluent wastewater in each of the studied wastewater treatment plants.

To the best of the author's knowledge, the evaluation of effluent quality of wastewater treatment plants in Jordan by using weighted arithmetic water quality index methodology has not been carried out yet. For the purpose evaluating the quality of water resources in Jordan for different uses by water quality indices, the studies performed by Ibrahim (M. Ibrahim, 2018; M. N. Ibrahim, 2019) presented the application of the water quality indices to evaluate the quality of groundwater for drinking purposes in main basins in Jordan. The results of this research will allow water managers and policymakers to interpret the treated water quality conditions for proper actions on water resources and agricultural management.

\section{DATA AND METHODOLOGY}

\section{Wastewater in Jordan and selected treatment plants}

Currently, there are more than 30 wastewater treatment plants in operation all over the country, with a total hydraulic load of 137387.5 cubic meters per day (MWI, 2017). The most commonly used wastewater treatment technologies are activated sludge systems and, to a lesser extent, trickling filters, waste stabilization ponds, and oxidation ditch. The sanitation coverage for both the urban and rural population exceeds $93 \%$ (MWI, $2016 \mathrm{~b}$ ). Out of which $65 \%$ are connected to the 
sewerage system and treatment plants in 2017 (MWI, 2017). This percentage is expected to increase to $80 \%$ by 2030 (MWI, 2016b).

In this study, twenty-two wastewater treatment plants were selected for collecting the treated effluent. The details of these treatment plants (treatment technology, operating or upgrade date, design, and actual hydraulic load and design and actual organic load) are given in Table 1. These treatment plants are part of the Ministry of Environment (MoE) national project for monitoring the water quality in Jordan sampling locations (MoE, 2016).

\section{Standards related to wastewater use in Jordan}

The Jordanian standards for reclaimed domestic wastewater (JS 893/2006) (JS, 2006), hereafter referred to as JS893/2006, is the current version of the Jordanian standard dealing with reclaimed domestic wastewater (earliest versions are JS 893/1995 and JS 893/2002). This standard is based mainly on the guidelines of the World Health Organization (WHO) and Food and Agricultural Organisation (FAO) (Ulimat, 2012). It specifies the conditions that the effluent quality from wastewater treatment plants should meet in order to be discharged into streams, wadis or water bodies or to be used for artificial recharge of groundwater aquifers and to be used for irrigation purposes. Regarding the irrigation purposes in JS 893/2006, there are four categories termed A, B, C, and D (see Table 2). Category A referred to the irrigation of vegetables that are normally eaten cooked, parking areas, sides of roads inside cities, and playgrounds. Category B referred to the irrigation of fruit trees, green areas, and sides of roads outside the cities. Category $\mathrm{C}$ referred to the irrigation of industrial crops, field crops, and forest trees. Category D referred to the irrigation of cut flowers (JS, 2006).

For the irrigation purposes, the reclaimed wastewater in Jordan is reused directly (i.e., without mixing with fresh water) and indirectly (i.e., after mixing with freshwater). The indirect reuse is practiced for unrestricted irrigation which allows irrigation of crops likely to be eaten uncooked. On the other hand, the direct reuse is practised for restricted irrigation which is limited to irrigating the crops that are mentioned in JS 893/2006 standard and categorized as A, B, C, and D. About $24 \%$ of the treated wastewater was directly used for irrigation in 2013 (WAJ, 2013). So far, the direct use of treated wastewater has been limited to fodder crops, olive trees, and forests trees in the areas directly near the treatment plants or through contracts with farmers. The treated wastewater from some of the selected wastewater treatment plants is fully used for direct irrigation, including Aqaba- Mechanical, Aqaba-Natural, Madaba, Mafraq, Ramtha, Kufranja, Wadi Mousa, Wadi Hassan, Karak and Al-Ekeder (WAJ, 2013). The direct reuse of the reclaimed water for irrigation of crops eaten raw such as cucumber, tomato, and lettuce is prohibited under the JS893/2006. For unrestricted irrigation, the effluent is firstly diluted in reservoirs and/or mixed with fresh water to increase its quality before being used in irrigation.

\section{Calculation of the WQI}

In this study, the WQI for reclaimed domestic wastewater is calculated by the weighted arithmetic mean method (Brown et al., 1970). The WQI is used here to evaluate the overall quality of the reclaimed domestic wastewater for irrigation purposes at selected treatment plants, with respect to JS 893/2006.

A set of fifteen most commonly used physical, chemical and microbiological water quality parameters were selected to include in the calculate WQI. These parameters are $\mathrm{pH}$, biochemical oxygen demand (BOD), chemical oxygen demand (COD), total dissolved solids (TDS), Total suspended solids (TSS), phosphate $\left(\mathrm{PO}_{4}^{-3}\right)$, chlorides $\left(\mathrm{Cl}^{-}\right)$, total nitrogen (TN), nitrates $\left(\mathrm{NO}_{3}^{-}\right)$, bicarbonate $\left(\mathrm{HCO}_{3}^{-}\right)$, sodium $\left(\mathrm{Na}^{+}\right)$, calcium $\left(\mathrm{Ca}^{+2}\right)$, magnesium $\left(\mathrm{Mg}^{+2}\right)$, Sodium Adsorption Ratio (SAR), and Escherichia coli (E.coli).

Including the microbiological parameters is important in any water quality assessment, since they reflect other physical and chemical parameters as well as the actual condition of water quality for different purposes (M.N. Ibrahim, 2019). The Escherichia coli (E.coli) microbiological parameter was not included in the calculation WQI for in category $\mathrm{C}$ since it was not specified in JS893/2006.

The data set for these parameters was obtained from the MoE monitoring program for the reclaimed domestic wastewater (MoE, 2016). The samples were collected from selected locations within one-year-monitoring period from March 2015 to February 2016. All sampling steps, including the preservation of samples and the analysis of all parameters, were carried out 
according to the standard methods for water and wastewater (APHA, 2005).

The WQI is obtained as per the following equation:

$$
W Q I=\sum_{i=1}^{n} W_{i} \times Q_{i} / \sum_{i=1}^{n} W_{i}
$$

where: $W_{i}$ is the unit weight of $i^{\text {th }}$ parameter,

$Q_{i}$ is the rating scale of $i^{\text {th }}$ parameter and

$n$ is the number of selected parameters

( $n=15$ for category A and B,

$n=14$ for category $\mathrm{C}$ in this study).

The rating scale $\left(Q_{i}\right)$ for each parameter is calculated according to the following equation:

$$
Q_{i}=\left(\frac{C_{i}-I_{i}}{S_{i}-I_{i}}\right) \times 100
$$

where: $Q_{i}$ is the rating scale,

$C_{i}$ is the concentration corresponding to $i^{\text {th }}$ parameter in $\mathrm{mg} / \mathrm{L}$ at a given sampling location, $I_{i}$ is the ideal value of $i^{\text {th }}$ parameter in pure water (i.e., The ideal value for $\mathrm{pH}=7$, and equal to zero for all other parameters), and $S_{i}$ is the reclaimed domestic wastewater standard for $i^{\text {th }}$ parameter in $\mathrm{mg} / \mathrm{L}$ according to JS893.

The unit weight $\left(W_{i}\right)$ is calculated using the (see Table 2)

$$
W_{i}=K / S_{i}
$$

where: $K$ is constant for proportionality and calculated by $K=1 / \sum_{1}^{n} \frac{1}{S_{i}}$

The water quality types according to the computed WQI values. These types are classified into five categories (Bora \& Goswami, 2017), as shown in Table 3.

\section{Effective weight calculation}

The effect of each water quality parameter on the WQI values was calculated by its effective weight. The effective weight $\left(E W_{i}\right)$ for each parameter was determined as in the following equations (M.N. Ibrahim, 2019; Şener et al., 2017):

$$
E W_{i}=\frac{W_{i} \times Q_{i}}{W Q I} \times 100
$$

where: $E W_{i}$ is the effective weight value for the $i^{\text {th }}$ parameter.

\section{RESULTS AND DISCUSSION}

\section{General characteristics of wastewater treatment plants effluent quality}

Table 1 shows that three wastewater treatment plants operated beyond its design capacity (i.e., hydraulically overloaded) and nine plants were overloaded in terms of the biochemical organic load in the year 2015. The data for the biochemical organic load is not available for five plants. The quality of the irrigation water may affect both crop yields and soil physical conditions. The selected physical, chemical and biological parameters which determine the irrigation water quality and are included in the WQI calculation are discussed below.

The mean of the effluent wastewater quality parameters in the selected wastewater treatment plants over the monitoring period is presented in Table 4, with minimum and maximum values among these treatment plants. The mean effluent $\mathrm{pH}$ values ranged from 6.84 in $\mathrm{S} 15$ to 8.35 also in S2, which indicates the slightly acidic to alkaline nature of effluent wastewater in all studied plants. As per JS893/2006, all values fall within the permissible limits (6.0 to 9.0) for main three categories $\mathrm{A}, \mathrm{B}$ and $\mathrm{C}$. This variation in the $\mathrm{pH}$ values is mainly due to the variation in the bicarbonate concentration in the effluent wastewater.

The mean effluent TDS value varies in the range $575 \mathrm{mg} / \mathrm{L}$ in $\mathrm{S} 13$ to $1962 \mathrm{mg} / \mathrm{L}$ in $\mathrm{S} 14$. The mean TDS values in all studied treatment plants are below the allowable limit of $1500 \mathrm{mg} / \mathrm{L}$ for the main three categories $\mathrm{A}, \mathrm{B}$, and $\mathrm{C}$ as per JS893/2006, except the studied plants S10 and S14, where the mean TDS concentrations are 1514 and $1962 \mathrm{mg} / \mathrm{L}$, respectively. For the TSS, JS893/2006 specified 50, 200 and $300 \mathrm{mg} / \mathrm{L}$ as the maximum allowable limit for category A, category $\mathrm{B}$ and category $\mathrm{C}$, respectively. The mean effluent TSS concentration varies from $4 \mathrm{mg} / \mathrm{L}$ in $\mathrm{S} 13$ to $381 \mathrm{mg} / \mathrm{L}$ in $\mathrm{S} 14$. Out of the 22 studied plants and according to the mean TSS values, nine plants (i.e., S1, S3,S4, S5, S6, S9, S14, S18, and S20) have the mean TSS concentration exceeding the maximum allowable limit for category $\mathrm{A}$, four plants (i.e., S1, S4, S6, and S14) have the mean TSS concentration exceeding the permissible limit for category B, and two plants (i.e., S6 and S14) have the mean TSS concentration exceeding the permissible limit for category $\mathrm{C}$. 
Table 1. Selected wastewater treatment plants basic information and their operation conditions in 2015

\begin{tabular}{|c|c|c|c|c|c|c|c|}
\hline \multirow[b]{2}{*}{ ID } & \multirow{2}{*}{$\begin{array}{l}\text { Treatment plant } \\
\text { Name }\end{array}$} & \multicolumn{2}{|c|}{$\begin{array}{c}\text { Hydraulic load } \\
\text { ( cubic meter/day) }\end{array}$} & \multicolumn{2}{|c|}{$\begin{array}{l}\text { Biochemical organic } \\
\text { load }\left(\mathrm{BOD}_{5}\right),(\mathrm{mg} / \mathrm{L})\end{array}$} & \multirow[b]{2}{*}{ Technology } & \multirow{2}{*}{$\begin{array}{c}\text { Operation - } \\
\text { upgrade } \\
\text { Year }\end{array}$} \\
\hline & & Design & $\begin{array}{c}\text { Actual daily } \\
\text { influent in } \\
2015^{a}\end{array}$ & Design & $\begin{array}{c}\text { Actual } \\
\text { BOD }_{5} \\
\text { in } 2015^{\text {b }}\end{array}$ & & \\
\hline S1 & Kufranja & 9000 & 2506 & 850 & 765 & Trickling Filter +Activated Sludge & 1989 \\
\hline S2 & Wadi Hassan & 1600 & 1594 & 800 & 1200 & Activated Sludge & 2001 \\
\hline S3 & Meyrad & 10000 & 6268 & 800 & 1200 & Activated Sludge & 2011 \\
\hline S4 & Aqaba-Natural & 9000 & 6699 & 900 & 420 & Waste Stab Ponds & 1987 \\
\hline S5 & Tafila & 7500 & 1450 & 1050 & 700 & Trickling Filter & 1988 \\
\hline S6 & Karak & 5500 & 1408 & 800 & 1200 & Activated Sludge & 1988 \\
\hline S7 & Madaba & 7600 & 6557 & 950 & $* * *$ & Activated Sludge & 1989 \\
\hline S8 & Wadi Esseir & 4000 & 5040 & 780 & 500 & Oxidation Ditch & 1997 \\
\hline S9 & Fuheis & 2400 & 2719 & 995 & 500 & Activated Sludge & 1997 \\
\hline $\mathrm{S} 10$ & Ramtha & 7400 & 4743 & 1000 & 1150 & Activated Sludge & 1987 \\
\hline S11 & Samra & 360000 & 294862 & 650 & 850 & Activated Sludge & 2008,1984 \\
\hline $\mathrm{S} 12$ & Wadi Mousa & 3400 & 2628 & 800 & $* * *$ & Activated Sludge & 2000 \\
\hline $\mathrm{S} 13$ & Aqaba-Mechanical & 12000 & 12475 & 420 & 420 & Activated Sludge & 2005 \\
\hline S14 & Ekedar & 4000 & 1918 & 1500 & $* * \star$ & Waste Stab Ponds & 2005 \\
\hline S15 & Abu Nuseir & 4000 & 3201 & 1100 & 900 & Activated Sludge & 1986 \\
\hline S16 & Baqa & 14900 & 11862 & 800 & 650 & Trickling Filter & 1987 \\
\hline S17 & Salt & 7700 & 7407 & 1090 & $* * *$ & Activated Sludge & 1981 \\
\hline S18 & Irbid Center & 11023 & 8143 & 800 & 1300 & Trickling Filter+ Activated Sludge & 1987 \\
\hline S19 & Wadi Arab & 21023 & 12880 & 995 & $* * *$ & Activated Sludge & 1999 \\
\hline S20 & Mafraq & 6050 & 3557 & 825 & $* \star \star$ & Waste Stab Ponds & 1988 \\
\hline S21 & Ma'an & 5772 & 2288 & 700 & 380 & Activated Sludge & 1989 \\
\hline S22 & $\begin{array}{l}\text { Mutah and } \\
\text { Adnaniyyah }\end{array}$ & 7060 & 1228 & 673 & 1120 & Activated Sludge & 2014 \\
\hline
\end{tabular}

a Source (MWI, 2015).

b Source (MoE, 2016).

The mean BOD recorded in the effluent of the selected wastewater treatment plants ranged between $3 \mathrm{mg} / \mathrm{L}$ in $\mathrm{S} 12$ and $365 \mathrm{mg} / \mathrm{L}$ in S6. According to JS893/2006, BOD up to $30 \mathrm{mg} / \mathrm{L}$ is the maximum allowable limit for category A, up to $200 \mathrm{mg} / \mathrm{L}$ is the maximum allowable limit for category B and up to $300 \mathrm{mg} / \mathrm{L}$ is the maximum allowable limit for category C. Out of the 22 studied plants, eight plants (i.e., S1, S3, S5, S6, S14, S18, S19, and S20) have the mean BOD exceeding the permissible limit for category A, three plants (i.e., S1, S6, and S14) have the mean BOD exceeding the permissible limit for category $\mathrm{B}$, and one plant (i.e., S6) has the mean BOD exceeding the permissible limit for category C. In the studied plants, the mean effluent COD values range from $25 \mathrm{mg} / \mathrm{L}$ in S13 to $2201 \mathrm{mg} / \mathrm{L}$ in S14. The maximum allowable limit of the COD to irrigate crops in category $\mathrm{A}$ is specified as $100 \mathrm{mg} / \mathrm{L}$ and 500 to irrigate crops in categories $\mathrm{B}$ and $\mathrm{C}$ as per the JS893/2006. Out of the 22 studied plants, twelve plants (i.e., S1, S3, S4, S5, S6, S8, S9, S14, S16, S18, S19, and S20) have the mean COD exceeding the permissible limit for category A. All of the mean COD values fall within the allowable limit for categories B and C except the studied plants $\mathrm{S} 1, \mathrm{~S} 6$ and S14 where the mean COD concentrations are 1158, 963 and $2201 \mathrm{mg} / \mathrm{L}$, respectively.

The mean effluent $\mathrm{PO}_{4}^{-3}$ effluent concentration ranges between $0.68 \mathrm{mg} / \mathrm{L}$ in $\mathrm{S} 21$ and $34.2 \mathrm{mg} / \mathrm{L}$ in $\mathrm{S} 6$. The mean $\mathrm{PO}_{4}^{-3}$ values in all studied plants are below the allowable limit of $30 \mathrm{mg} / \mathrm{L}$ as per JS893/2006 for main three categories A, B, and $\mathrm{C}$, except the sample locations S5, S6, and S10 where the mean $\mathrm{PO}_{4}^{-3}$ concentration is $32.1,34.2$ and $32.9 \mathrm{mg} / \mathrm{L}$, respectively. The mean effluent concentration of $\mathrm{Cl}^{-}$is observed from $119 \mathrm{mg} / \mathrm{L}$ in $\mathrm{S} 1$ and $1167 \mathrm{mg} / \mathrm{L}$ in $\mathrm{S} 14$. The mean $\mathrm{Cl}^{-}$values in all studied plants are below the allowable limit of $400 \mathrm{mg} / \mathrm{L}$ for the main three categories A, B and C as per JS893/2006 except the studied plants $\mathrm{S} 10$ and $\mathrm{S} 14$ where the mean $\mathrm{Cl}^{-}$concentrations are 528 and $1167 \mathrm{mg} / \mathrm{L}$, respectively. The mean effluent value of $\mathrm{Na}^{+}$for the selected wastewater treatment plant ranged between $75 \mathrm{mg} / \mathrm{L}$ in $\mathrm{S} 1$ and 395 in $\mathrm{S} 14 \mathrm{mg} / \mathrm{L}$. The mean $\mathrm{Na}^{+}$values in 
Table 2 The unit weight of each parameter used for WQI computation with Jordanian standards for reclaimed domestic wastewater

\begin{tabular}{|c|c|c|c|c|c|c|c|c|}
\hline \multirow{3}{*}{ Parameters } & \multirow{2}{*}{\multicolumn{4}{|c|}{$\begin{array}{l}\text { JS 893/2006 } \\
\text { maximum allowable limits for different } \\
\text { reuse categories }\end{array}$}} & \multirow{2}{*}{\multicolumn{4}{|c|}{ Unit weight }} \\
\hline & & & & & & & & \\
\hline & A & B & C & D & A & B & C & D \\
\hline $\mathrm{pH}$ & $6.0-9.0$ & $6.0-9.0$ & $6.0-9.0$ & $6.0-9.0$ & 0.272 & 0.337 & 0.355 & 0.081 \\
\hline $\begin{array}{l}\text { Biochemical oxygen demand (BOD), } \\
\mathrm{mg} / \mathrm{L}\end{array}$ & 30 & 200 & 300 & 15 & 0.082 & 0.015 & 0.011 & 0.048 \\
\hline Chemical oxygen demand (COD), mg/L & 100 & 500 & 500 & 50 & 0.024 & 0.006 & 0.006 & 0.015 \\
\hline Total dissolved solid (TDS), mg/L & 1500 & 1500 & 1500 & 1500 & 0.002 & 0.002 & 0.002 & 0.000 \\
\hline Total suspended solids (TSS), mg/L & 50 & 200 & 300 & 15 & 0.049 & 0.015 & 0.011 & 0.048 \\
\hline Phosphate $\left(\mathrm{PO}_{4}^{-3}\right), \mathrm{mg} / \mathrm{L}$ & 30 & 30 & 30 & 30 & 0.082 & 0.101 & 0.107 & 0.024 \\
\hline Chlorides $\left(\mathrm{Cl}^{-}\right), \mathrm{mg} / \mathrm{L}$ & 400 & 400 & 400 & 400 & 0.006 & 0.008 & 0.008 & 0.002 \\
\hline Total nitrogen (TN), mg/L & 45 & 70 & 100 & 70 & 0.054 & 0.043 & 0.032 & 0.010 \\
\hline Nitrates $\left(\mathrm{NO}_{3}^{-}\right), \mathrm{mg} / \mathrm{L}$ & 30 & 45 & 70 & 45 & 0.082 & 0.067 & 0.046 & 0.016 \\
\hline Bicarbonate $\left(\mathrm{HCO}_{3}^{-}\right), \mathrm{mg} / \mathrm{L}$ & 400 & 400 & 400 & 400 & 0.006 & 0.008 & 0.008 & 0.002 \\
\hline Sodium $\left(\mathrm{Na}^{+}\right), \mathrm{mg} / \mathrm{L}$ & 230 & 230 & 230 & 230 & 0.011 & 0.013 & 0.014 & 0.003 \\
\hline Calcium $\left(\mathrm{Ca}^{+2}\right), \mathrm{mg} / \mathrm{L}$ & 230 & 230 & 230 & 230 & 0.011 & 0.013 & 0.014 & 0.003 \\
\hline Magnesium $\left(\mathrm{Mg}^{+2}\right), \mathrm{mg} / \mathrm{L}$ & 100 & 100 & 100 & 100 & 0.024 & 0.030 & 0.032 & 0.007 \\
\hline Sodium Adsorption Ratio (SAR) & 9 & 9 & 9 & 9 & 0.272 & 0.337 & 0.355 & 0.081 \\
\hline Escherichia coli(E.coli), MPNa/100 mL & 100 & 1000 & $-b$ & 1.1 & 0.024 & 0.003 & - & 0.659 \\
\hline
\end{tabular}

a MPN: Most Probable Number.

${ }^{\mathbf{b}}$ Not specified

Table 3 The WQI range and water quality classification for irrigation purposes

\begin{tabular}{|c|l|}
\hline WQI range & \multicolumn{1}{|c|}{ Type of water } \\
\hline$<25$ & Excellent water \\
\hline $26-50$ & Good water \\
\hline $51-75$ & Poor water \\
\hline $76-100$ & Very poor water \\
\hline$>100$ & Water unsuitable for the intended use \\
\hline
\end{tabular}

the studied plant S10, S14 and S20 exceeded the permissible limit of $230 \mathrm{mg} / \mathrm{L}$ for main three categories A, B, and C, as per JS893/2006. The mean $\mathrm{Na}^{+}$concentrations are 335,395 and $243 \mathrm{mg} / \mathrm{L}$, respectively.

According to JS893/2006, the maximum allowable limits of the TN to irrigate crops in categories A, B and C are specified as 45, 70 and $100 \mathrm{mg} / \mathrm{L}$, respectively. The mean effluent value of TN in the studied plants ranges from $5 \mathrm{mg} / \mathrm{L}$ in $\mathrm{S} 5$ to $192 \mathrm{mg} / \mathrm{L}$ in S14. Out of 22 studied plants, the mean TN values in eleven plants (i.e., S1, S4, S5, S6, S8, S14, S16, S17, S18, S19, and S20) exceeded the permissible limit for category A, seven plants (i.e., S1, S5, S6, S8, S14, S18, and S20) exceeded the permissible limit for category B, and three plants (i.e., S1, S6, S14, and S18) exceeded the permissible limit for category $\mathrm{C}$. The mean effluent value of $\mathrm{NO}_{3}{ }^{-}$in the studied plants is observed between less than one $\mathrm{mg} / \mathrm{L}$ in three plants (S3, S17, and S19) and $76 \mathrm{mg} / \mathrm{L}$ in S17. Out of the 22 studied plants, five plants (i.e., S11, S12, S15, S16, and S20) have the mean $\mathrm{NO}_{3}{ }^{-}$exceeding the permissible limit of $30 \mathrm{mg} / \mathrm{L}$ for category A, three plants (i.e., S11, S15, and $\mathrm{S} 16)$ have the mean $\mathrm{NO}_{3}^{-}$exceeding the permissible limit of $45 \mathrm{mg} / \mathrm{L}$ for category $\mathrm{B}$, and one plant (i.e., S16) has the mean $\mathrm{NO}_{3}^{-}$exceeding the permissible limit of $70 \mathrm{mg} / \mathrm{L}$ for category $\mathrm{C}$. The mean effluent concentration of $\mathrm{HCO}_{3}^{-}$is varied from $92 \mathrm{mg} / \mathrm{L}$ in S15 and $1082 \mathrm{mg} / \mathrm{L}$ in S6. Most of the mean effluent $\mathrm{HCO}_{3}^{-3}$ values in the studied plants (13 out of 22 plants) are above the allowable limit of $400 \mathrm{mg} / \mathrm{L}$ for main three categories A, B, and C, as per JS893/2006.

The results showed that none of the $\mathrm{Ca}^{+2}$, $\mathrm{Mg}^{+2}$ and SAR effluent concentrations exceeded the permissible limit of $230 \mathrm{mg} / \mathrm{L}, 100 \mathrm{mg} / \mathrm{L}$ and 9 for main three categories $\mathrm{A}, \mathrm{B}$ and $\mathrm{C}$, respectively, as per JS893/2006. The $\mathrm{Ca}^{+2}, \mathrm{Mg}^{+2}$ and SAR mean values are found to be in the range from 57 in $\mathrm{S} 13$ to $121 \mathrm{mg} / \mathrm{L}$ in S6, in the range from $15 \mathrm{mg} / \mathrm{L}$ in S13 to $43 \mathrm{mg} / \mathrm{L}$ in S12 and in the range from 1.81 in $\mathrm{S} 1$ to 8.21 in S14, respectively. The range of the mean E.coli count is found to vary between less than 1.8 MPN per $100 \mathrm{~mL}$ in $\mathrm{S} 12$ and S15 and 6470000 MPN per $100 \mathrm{~mL}$ in S1. The JS893/2006 for E.coli allows the most 
Table 4. Mean values ${ }^{a}$ of the measured effluent quality parameters used in this study at each wastewater treatment plant during the monitoring period. The minimum and maximum values are among the sampling locations

\begin{tabular}{|c|c|c|c|c|c|c|c|c|c|c|c|c|c|c|c|c|}
\hline \multirow{2}{*}{ ID } & \multirow{2}{*}{$\begin{array}{l}\text { Wastewater } \\
\text { treatment plant }\end{array}$} & \multicolumn{15}{|c|}{ Parameters } \\
\hline & & $\mathrm{pH}$ & BOD & COD & TDS & TSS & $\mathrm{PO}_{4}^{-3}$ & $\mathrm{Cl}^{-}$ & TN & $\mathrm{NO}_{3}^{-}$ & $\mathrm{HCO}_{3}^{-}$ & $\mathrm{Na}^{+}$ & $\mathrm{Ca}^{+2}$ & $\mathrm{Mg}^{+2}$ & SAR & E.coli \\
\hline S1 & Kufranja & 7.58 & 228 & 1158 & 680 & 266 & 12.3 & 119 & 132 & 4.06 & 548 & 76 & 106 & 17 & 1.81 & $6.47 \mathrm{E}+06$ \\
\hline S2 & Wadi Hassan & 8.35 & 7 & 59 & 844 & 17 & 8.3 & 206 & 9 & 3.8 & 384 & 163 & 83 & 28 & 3.95 & $1.43 E+01$ \\
\hline S3 & Meyrad & 7.38 & 46 & 315 & 996 & 71 & 0.92 & 275 & 45 & $<1.0$ & 418 & 196 & 117 & 23 & 4.33 & $1.63 E+01$ \\
\hline S4 & Aqaba-Natural & 7.61 & 18 & 426 & 752 & 207 & 2.2 & 177 & 62 & 7.35 & 493 & 155 & 67 & 24 & 4.15 & $1.00 \mathrm{E}+04$ \\
\hline S5 & Tafila & 7.46 & 97 & 456 & 988 & 53 & 32.1 & 204 & 91 & 1.5 & 691 & 171 & 83 & 41 & 3.85 & $1.48 E+05$ \\
\hline S6 & Karak & 7.46 & 365 & 963 & 1142 & 330 & 34.2 & 279 & 127 & 1.01 & 1082 & 191 & 121 & 16 & 4.33 & $1.88 E+06$ \\
\hline S7 & Madaba & 7.79 & 15 & 76 & 984 & 15 & 1.02 & 277 & 40 & 1.6 & 440 & 245 & 77 & 26 & 6.16 & $4.38 E+04$ \\
\hline S8 & Wadi Esseir & 7.73 & 23 & 318 & 708 & 20 & 20.7 & 155 & 74 & 3.2 & 540 & 112 & 89 & 19 & 2.81 & $3.80 E+00$ \\
\hline s9 & Fuheis & 7.62 & 11 & 125 & 784 & 96 & 2.39 & 166 & 19.8 & 13.5 & 270 & 125 & 100 & 21 & 2.96 & $3.76 E+04$ \\
\hline $\mathrm{S} 10$ & Ramtha & 7.73 & 5 & 88 & 1514 & 23 & 32.9 & 528 & 63 & 4.4 & 781 & 335 & 119 & 41 & 6.75 & $1.01 \mathrm{E}+03$ \\
\hline S11 & Samra & 7.53 & 6 & 41 & 935 & 9 & 6.22 & 288 & 18.8 & 53.9 & 310 & 207 & 75 & 19 & 5.52 & $1.08 \mathrm{E}+01$ \\
\hline $\mathrm{S} 12$ & Wadi Mousa & 7.69 & 3 & 25 & 854 & 7 & 9.22 & 224 & 14.6 & 43.4 & 291 & 144 & 86 & 43 & 3.16 & $<1.8$ \\
\hline S13 & Aqaba-Mechanical & 7.23 & 4 & 25 & 575 & 4 & 2.02 & 160 & 5 & 1.7 & 186 & 136 & 57 & 15 & 4.15 & $1.04 \mathrm{E}+01$ \\
\hline S14 & Ekedar & 8.05 & 209 & 2201 & 1962 & 381 & 26.6 & 1167 & 192 & 3.1 & 1000 & 395 & 110 & 40 & 8.21 & $2.52 \mathrm{E}+04$ \\
\hline S15 & Abu Nuseir & 6.84 & 6 & 45 & 804 & 8 & 12.8 & 199 & 18.1 & 54.69 & 92 & 153 & 65 & 20 & 4.26 & $<1.8$ \\
\hline S16 & Baqa & 7.87 & 23 & 101 & 993 & 19 & 16.9 & 233 & 55.9 & 76 & 250 & 202 & 90.3 & 31.3 & 4.67 & $2.10 \mathrm{E}+05$ \\
\hline S17 & Salt & 7.59 & 22 & 86 & 755 & 30 & 8.9 & 175 & 52.3 & $<1.0$ & 447 & 139 & 79 & 27 & 3.45 & $2.80 \mathrm{E}+04$ \\
\hline S18 & Irbid Center & 7.77 & 115 & 361 & 1272 & 124 & 21.5 & 309 & 74 & 1.6 & 893 & 228 & 108 & 33 & 4.92 & $2.32 \mathrm{E}+04$ \\
\hline $\mathrm{S} 19$ & Wadi Arab & 7.9 & 39 & 101 & 1034 & 31 & 14 & 230 & 53 & $<1.0$ & 631 & 195 & 108 & 30 & 4.28 & $4.33 \mathrm{E}+03$ \\
\hline S20 & Mafraq & 7.92 & 100 & 427 & 1222 & 109 & 14.5 & 287 & 80 & 40 & 900 & 243 & 90 & 37 & 5.44 & $9.18 \mathrm{E}+04$ \\
\hline S21 & Ma'an & 8.12 & 10 & 44 & 919 & 6 & 0.67 & 214 & 12.6 & 26.6 & 340 & 173 & 93 & 39 & 3.8 & $1.02 \mathrm{E}+02$ \\
\hline S22 & $\begin{array}{l}\text { Mutah and } \\
\text { Adnaniyyah }\end{array}$ & 7.82 & 5 & 33 & 1039 & 6 & 11 & 268 & 30.2 & 9 & 389 & 190 & 110 & 32 & 4 & $1.30 \mathrm{E}+02$ \\
\hline & Minimum & 8.35 & 365 & 2201 & 1962 & 381 & 34.2 & 1167 & 192 & 76 & 1082 & 395 & 121 & 43 & 8.21 & $6.47 E+06$ \\
\hline & Maximum & 6.84 & 3 & 25 & 575 & 4 & 0.67 & 119 & 5 & 1.0 & 92 & 76 & 57 & 15 & 1.81 & 1.8 \\
\hline
\end{tabular}

a The mean is the arithmetic mean for all parameters except for $E$. coli geometric mean.

All values in mg/l except and E.coli in MPN/100 mL, pH and SAR are dimensenless.

Reference: National Project for Monitoring Water Quality in Jordan: Annual report 2015-2016 (MoE, 2016).

probable number (MPN) of 100 per $100 \mathrm{~mL}$ to irrigate crops in category A, 1000 per $100 \mathrm{~mL}$ to irrigate crops in category $\mathrm{B}$ and not specified to irrigate crops in category C. Most of the mean effluent $E$.coli counts in the studied plants exceeded the maximum allowable limit for the categories A and B with noticeably high level in some plants. The mean E.coli count exceeded the maximum allowable limit in 15 studied plants for category A and 13 studied plants for category B.

\section{Assessment of the wastewater treatment plants effluent using WQI}

During the study period, the WQI values and the corresponding water quality type in the studied plants are presented in Table 5. From the computed WQI values for category A, the suitability effluent quality of the studied plants to irrigate crops in category A ranges from "excellent" to "water unsuitable for intended use" range. The results from Table 5 for category A indicated that out of 22 studied locations, one plant is classified in the 'Excellent water' class, Six plants as a "Good water" class, two as a "Poor water" class, one as a "Very poor water" class and twelve plants are classified in the "Water unsuitable for intended use" class.

The suitability effluent quality of the studied plants to irrigate crops in category $\mathrm{B}$ is in the "excellent" to "water unsuitable for intended use" range. The results from Table 5 for category $\mathrm{B}$ indicated that out of 22 studied locations, one plant is classified in the "Excellent water" class, twelve plants as a "Good water" class, three as a "Poor water" class, three as a "Very poor water" class and three plants are classified in the "Water unsuitable for intended use" class.

The suitability effluent quality of the studied plants to irrigate crops in category $\mathrm{C}$ is in the "excellent" to "very poor water" range. The results from Table 5 for category $\mathrm{C}$ indicated that out of 
Table 5. Results of water quality index for irrigation purposes of the studied wastewater treatment plants effluent

\begin{tabular}{|c|c|c|c|c|c|c|}
\hline \multirow{2}{*}{ ID } & \multicolumn{2}{|r|}{ Category A } & \multicolumn{2}{|r|}{ Category B } & \multicolumn{2}{|r|}{ Category C } \\
\hline & WQI & Water Type & WQI & Water Type & WQI & Water Type \\
\hline S1 & 158418 & Water unsuitable for intended use & 2002 & $\begin{array}{l}\text { Water unsuitable for } \\
\text { intended use }\end{array}$ & 33 & Good water \\
\hline $\mathrm{S} 2$ & 43 & Good water & 45 & Good water & 47 & Good water \\
\hline S3 & 55 & Poor water & 31 & Good water & 31 & Good water \\
\hline S4 & 314 & Water unsuitable for intended use & 40 & Good water & 35 & Good water \\
\hline S5 & 3705 & Water unsuitable for intended use & 90 & Very Poor water & 44 & Good water \\
\hline S6 & 46191 & Water unsuitable for intended use & 626 & $\begin{array}{l}\text { Water unsuitable for } \\
\text { intended use }\end{array}$ & 51 & Poor water \\
\hline S7 & 1117 & Water unsuitable for intended use & 57 & Poor water & 45 & Good water \\
\hline S8 & 52 & Poor water & 39 & Good water & 38 & Good water \\
\hline S9 & 962 & Water unsuitable for intended use & 41 & Good water & 29 & Good water \\
\hline S10 & 84 & Very Poor water & 60 & Poor water & 61 & Poor water \\
\hline S11 & 49 & Good water & 45 & Good water & 41 & Good water \\
\hline $\mathrm{S} 12$ & 40 & Good water & 38 & Good water & 35 & Good water \\
\hline $\mathrm{S} 13$ & 21 & Excellent water & 23 & Excellent water & 24 & Excellent water \\
\hline S14 & 842 & Water unsuitable for intended use & 93 & Very Poor water & 81 & Very Poor water \\
\hline S15 & 37 & Good water & 30 & Good water & 25 & Good water \\
\hline S16 & 5208 & Water unsuitable for intended use & 121 & $\begin{array}{l}\text { Water unsuitable for } \\
\text { intended use }\end{array}$ & 51 & Poor water \\
\hline S17 & 726 & Water unsuitable for intended use & 42 & Good water & 33 & Good water \\
\hline S18 & 665 & Water unsuitable for intended use & 58 & Poor water & 50 & Poor water \\
\hline S19 & 161 & Water unsuitable for intended use & 46 & Good water & 45 & Good water \\
\hline $\mathrm{S} 20$ & 2352 & Water unsuitable for intended use & 87 & Very Poor water & 55 & Poor water \\
\hline S21 & 46 & Good water & 42 & Good water & 41 & Good water \\
\hline S22 & 42 & Good water & 40 & Good water & 40 & Good water \\
\hline
\end{tabular}

Note: water type for category D is "Water unsuitable for intended use" for all studied plants.

22 studied locations, one plant is classified in the "Excellent water" class, fifteen plants as a "Good water" class, five as a "Poor water" class and one as a "Very poor water" class. None of the studied locations are classified in the "Water unsuitable for intended use" class. The effluent quality of all studied plants is unsuitable for irrigating cut flowers (i.e., for category D).

The effluent quality of the Aqaba-Mechanical wastewater treatment plant (S13) shows "Excellent water" class to irrigate crops in categories $\mathrm{A}, \mathrm{B}$, and $\mathrm{C}$. This may be due to the relatively low measured effluent concentration values of all selected parameters in comparison to their maximum allowable limit values as prescribed in the JS893/2006 for main three categories A, B, and C. The As Samra wastewater treatment plant (S11), which is the largest wastewater treatment plant in Jordan is of particular concern. The plant treats more than 70 percent of all wastewater produced in Jordan (MWI, 2016a) and provides treated water accounting for more than 10 percent of Jordan's entire water resources. The effluent quality of the S11 plant shows "Good water" class to irrigate crops in categories A, B and C. In addition to the S11 plant, the effluent quality of five plants namely Wadi Hassan (S2), Wadi Mousa (S12), Abu Nuseir (S15), Ma'an (S21) and Mutah and Adnaniyyah (S22) show "Good water" class to irrigate crops in categories A, B, and C.

For the remaining selected treatment plants, "Good water" class, "Poor water" class, "Very poor water" class and "Water unsuitable for intended use" class have been observed based on category. This may be due to relatively high measured effluent concentration values of the most selected parameters, especially E.coli count, in comparison to their maximum allowable limit values as prescribed in JS893/2006 for main three categories A, B, and C. The high measured effluent concentration values reflect the low removal efficiency due to the existing treatment process and the influent concentrations exceeding the design value. 
The effective weight values of each water quality parameter are obtained by using Equation (4). The mean and standard deviations of the effective weight values for each water quality parameter in all studied plants based on category are present in Table 6. From Table 6, for category A, the outcome revealed that $E$. coli represents the largest mean effective weight (i.e., 51.17\%) among all other parameters. The water quality parameters $\mathrm{SAR}, \mathrm{pH}, \mathrm{NO}_{3}{ }^{-}$and $\mathrm{BOD}$ also contributed to the index value in category $\mathrm{A}$ with effective weight of $14.55 \%, 9.24 \%, 5.99 \%$, and $4.01 \%$, respectively. For category B, the largest mean effective weights values refer to the water quality parameters SAR, $\mathrm{pH}$ and $E$. coli with effective weight of $32.64 \%, 21.55 \%$, and $19.42 \%$, respectively. While for category $\mathrm{C}$, the $\mathrm{SAR}, \mathrm{pH}$ and $\mathrm{PO}_{4}^{-3}$ parameters represent the largest mean effective weight of $42.09 \%, 28.25 \%$, and $10.47 \%$, respectively. Thus, these aforementioned parameters based on category are considered as the main parameters which degrade the effluent wastewater quality (i.e., most effective parameters in the WQI values).

A strong relationship is found between the unit weight $\left(W_{i}\right)$ in Table 2 and the mean effective weight $\left(E W_{i}\right)$ in Table 6 for each parameter (i.e., high unit weight also shows high effective weight) except for the E.coli count. The E.coli count has the highest mean effective weights in category A and the third-highest mean effective

Table 6. Mean and standard deviations of effective weight values for each water quality parameter

\begin{tabular}{|c|c|c|c|}
\hline \multirow{2}{*}{ Parameters } & \multicolumn{3}{|c|}{ Effective weight (\%) Mean \pm SD } \\
\cline { 2 - 4 } & Category A & Category B & Category C \\
\hline $\mathrm{pH}$ & $9.42 \pm 12.69$ & $21.55 \pm 13.8$ & $28.25 \pm 12.58$ \\
\hline $\mathrm{BOD}$ & $4.01 \pm 5.13$ & $0.45 \pm 0.48$ & $0.48 \pm 0.72$ \\
\hline $\mathrm{COD}$ & $2.85 \pm 4.06$ & $0.49 \pm 0.65$ & $0.93 \pm 1.18$ \\
\hline $\mathrm{TDS}$ & $0.11 \pm 0.11$ & $0.25 \pm 0.1$ & $0.34 \pm 0.05$ \\
\hline $\mathrm{TSS}^{2}$ & $2.27 \pm 2.85$ & $0.78 \pm 1.04$ & $0.67 \pm 0.84$ \\
\hline $\mathrm{PO}_{4}^{-3}$ & $2.80 \pm 3.72$ & $6.92 \pm 5.61$ & $10.47 \pm 7.51$ \\
\hline $\mathrm{Cl}^{-}$ & $0.41 \pm 0.42$ & $0.97 \pm 0.53$ & $1.25 \pm 0.46$ \\
\hline $\mathrm{TN}^{-}$ & $3.70 \pm 4.26$ & $5.19 \pm 3.54$ & $4.17 \pm 2.94$ \\
\hline $\mathrm{NO}_{3}{ }^{-}$ & $5.99 \pm 11.75$ & $4.88 \pm 7.38$ & $2.71 \pm 3.92$ \\
\hline $\mathrm{HCO}_{3}^{-}$ & $0.61 \pm 0.6$ & $1.65 \pm 0.8$ & $2.37 \pm 0.89$ \\
\hline $\mathrm{Na}^{+}$ & $0.91 \pm 0.94$ & $2.10 \pm 0.93$ & $2.71 \pm 0.58$ \\
\hline $\mathrm{Ca}^{+2}$ & $0.45 \pm 0.46$ & $1.02 \pm 0.49$ & $1.39 \pm 0.37$ \\
\hline $\mathrm{Mg}^{+2}$ & $0.75 \pm 0.82$ & $1.68 \pm 0.78$ & $2.19 \pm 0.61$ \\
\hline $\mathrm{SAR}^{2}$ & $14.55 \pm$ & $32.64 \pm$ & $42.09 \pm 11.31$ \\
\hline $\mathrm{E.coli}^{-}$ & 16.14 & 15.66 & \\
\hline & $51.17 \pm$ & $19.42 \pm$ & Not included \\
\hline
\end{tabular}

weights in category $\mathrm{B}$, and at the same time has low unit weight. This finding is mainly due to the very high measured concentration values of the E.coli count in most of the treatment plants effluent, in comparison to its maximum allowable limit values, as prescribed in the JS893/2006, Table 4.

Numerous water quality studies have demonstrated that the existence of E.coli (i.e., microbial pollutant) in the effluent of wastewater reuse for agriculture is harmful for the crops growth, has a potential to damage the soil and develops the risk of disease for the consumers and the farmworkers (Al-hammad et al., 2014; Forslund et al., 2010; F. Jaramillo, 2017; M. F. Jaramillo \& Restrepo, 2017). In order to reduce the E.coli load from wastewater treatment plants, some additional advance treatment is recommended (Fatta-kassinos et al., 2015; Norton-Brandão et al., 2013).

\section{CONCLUSIONS}

This study presents the application of WQI in evaluating the suitability of the effluent quality of selected wastewater treatment plants in Jordan for irrigation purposes. On the basis of the result, the following specific conclusions can be drawn:

- According to WQI scale classification, most of the selected wastewater treatment plants were not in full compliance with the Jordanian standards for reclaimed domestic wastewater (JS 893/2006) regarding the direct reuse of treated wastewater for the irrigation purposes.

- Regarding the suitability of the effluent quality of the studied plants to irrigate crops in category A, one plant is classified in the "Excellent water" class, Six plants as a "Good water" class, two as a "Poor water" class, one as a "Very poor water" class and twelve plants are classified in the "Water unsuitable for intended use' class.

- Regarding the suitability of the effluent quality of the studied plants to irrigate crops in category $\mathrm{B}$, one plant is classified in the "Excellent water" class, twelve plants as a "Good water" class, three as a "Poor water" class, three as a "Very poor water" class and three plants are classified in the "Water unsuitable for intended use" class.

- Regarding the suitability effluent quality of the studied plants to irrigate crops in category $\mathrm{C}$, one plant is classified in the "Excellent water" class, fifteen plants as a "Good 
water" class, five as a "Poor water" class and one as a "Very poor water" class. None of the studied locations are classified in the "Water unsuitable for intended use" class.

- The effluent quality of all studied plants is unsuitable for irrigating cut flowers (i.e., for category D).

- According to the effective weight values, $E$. coli is considered the most effective parameter in the WQI values in category $\mathrm{A}$. and, to a lesser extent, $\mathrm{SAR}, \mathrm{pH}, \mathrm{BOD}$, and $\mathrm{NO}_{3}^{-}$. For category $\mathrm{B}$, the SAR, $\mathrm{pH}$ and $E$. coli parameters are considered the most effective parameter in the WQI values. In turn, for category $\mathrm{C}$, the SAR, $\mathrm{pH}$ and $\mathrm{PO}_{4}^{-3}$ parameters are considered the most effective parameter in the WQI values. Thus, these afore-mentioned parameters based on category are considered as the main parameters which degrade the effluent wastewater quality.

- In terms of application, the results of this study are beneficial for the water managers and policymakers for proper actions on water resources and agricultural management in Jordan, especially when considering the use of treated wastewater for restricted and unrestricted irrigation practices. Furthermore, in order to protect the environment and public health, enhancement of microbial and physicochemical pollutant removal processes in most of selected wastewater treatment plants to produce the effluent quality in line with the Jordanian standards for reclaimed domestic wastewater is recommended.

\section{Acknowledgements}

The author would like to thank the Ministry of Environment in Jordan for providing the required water quality data.

\section{REFERENCES}

1. Abbasi, T., \& Abbasi, S.A. 2012. Water Quality Indices (1st Edition). Elsevier. DOI:10.1016/ B978-0-444-54304-2.00001-4

2. Al-hammad, B.A.,Abd, M.M., \& Ibrahim, S.Y. 2014. Quality of wastewater reuse in agricultural irrigation and its impact on public health. DOI:10.1007/ s10661-014-3961-9

3. APHA. 2005. Standard Methods for the Examination of Water and Wastewater (21st edition). Washington, DC: American Public Health Association.
4. Bora, M., \& Goswami, D.C. 2017. Water quality assessment in terms of water quality index ( WQI ): case study of the Kolong River, Assam , India. Applied Water Science, 7(6), 3125-3135. DOI:10.1007/s13201-016-0451-y

5. Brown, R.M., McClelland, N.I., Deininger, R.A., \& Tozer, R.G. 1970. A Water Quality Index: Do We Dare? Water Sewage Works, 117(10), 339-343.

6. Candela, L., Fabregat, S., Josa, A., Suriol, J., Vigués, N., \& Mas, J. 2007. Assessment of soil and groundwater impacts by treated urban wastewater reuse. A case study: Application in a golf course (Girona, Spain). Science of The Total Environment, 374(1), 26-35. DOI:https://doi.org/10.1016/j. scitotenv.2006.12.028

7. Debels, P., Figueroa, R., Urrutia, R., Barra, R., \& Niell, X. 2005. Evaluation of Water Quality in the Chillán River (Central Chile) Using Physicochemical Parameters and a Modified Water Quality Index. Environmental Monitoring and Assessment, 110(13), 301-322. DOI:10.1007/s10661-005-8064-1

8. Fatta-kassinos, D., Kummerer, K., \& Dionysiou, D. 2015. Advanced Treatment Technologies for Urban Wastewater. Springer International Publishing. DOI:10.1007/698_2015_359

9. Fatta, D., Alaton, I. A., Gokcay, C., Skoula, I., Papadopoulos, A., \& Loizidou, M. 2004. Wastewater Reuse in the Mediterranean Basin-Problems and Challenges. In N. B. Harmancioglu, O. Fistikoglu, Y. Dalkilic, \& A. Gul (Eds.), Water resources management: risks and challenges for the 21 st century (pp. 499-508). Izmir, 2-4 September 2004.

10. Forslund, A., Ensink, J. H. J., Battilani, A., Kljujev, I., Gola, S., Raicevic, V., ... Dalsgaard, A. 2010. Faecal contamination and hygiene aspect associated with the use of treated wastewater and canal water for irrigation of potatoes (Solanum tuberosum). Agricultural Water Management, 98(3), 440-450. DOI:https://doi.org/10.1016/j.agwat.2010.10.007

11. Horton, R.K. 1965. An index number system for rating water quality. Journal of Water Pollution Control Federation, 37(3), 300-306.

12. Ibrahim, M. 2018. Evaluation of groundwater quality suitability for drinking purpose using water quality index approach in Yarmouk basin, Jordan. Jordanian Journal of Engineering and Chemical Industries, 1(2), 84-92.

13. Ibrahim, M.N. 2019.Assessing Groundwater Quality for Drinking Purpose in Jordan: Application of Water Quality Index. Journal of Ecological Engineering, 20(3), 101-111. DOI:10.12911/22998993/99740

14. Jaramillo, F. 2017. Wastewater Reuse in Agriculture : A Review about Its Limitations and Benefits. DOI:10.3390/su9101734

15. Jaramillo, M.F., \& Restrepo, I. 2017. Wastewater Reuse in Agriculture: A review about its limitations and benefits. Sustainability, 9(10). DOI:10.3390/ su9101734 
16. Jeong, H., Jang, T., Seong, C., Park, S. 2014. Assessing nitrogen fertilizer rates and split applications using the DSSAT model for rice irrigated with urban wastewater. Agricultural Water Management, 141, 1-9. DOI:https://doi.org/10.1016/j. agwat.2014.04.009

17. Jiménez, B. and Asano, T. 2008, May 1 Water reuse: An international survey of current practice, issues and needs. IWA Publishing. DOI: $10.2166 / 9781780401881$

18. JS. 2006. Jordanian Standard 893-2006 on Water/ Reclaimed domestic wastewater. Jordan Standards and Metrology Organization, Amman, Jordan.

19. Lumb, A., Sharma, T.C., Bibeault, J.-F. 2011. A Review of Genesis and Evolution of Water Quality Index (WQI) and Some Future Directions. Water Quality, Exposure and Health, 3(1), 11-24. DOI: $10.1007 /$ s12403-011-0040-0

20. Lyu, S., Chen, W., Zhang, W., Fan, Y., Jiao, W. 2015. Wastewater reclamation and reuse in China: Opportunities and challenges. JES, 1-11. DOI:10.1016/j. jes.2015.11.012

21. MoE. 2016. National Project for Monitoring Water Quality in Jordan: Annual report 2015-2016. Ministry of Environment (MOE). Amman, Jordan. Retrieved from http://moenv.gov.jo/AR/Documents/report2017/I

22. MWI. 2002. Jordan's Water Strategy and Policies. Ministry of Water and Irrigation (MWI), Amman, Jordan.

23. MWI. 2015. Jordan Water Sector Facts \& Figures 2015. Ministry of Water and Irrigation. Ministry of Water and Irrigation (MWI), Amman, Jordan.

24. MWI. 2016a. Annual Report of Water Authority Jordan valley. Ministry of Water and Irrigation of Jordan, Amman, Jordan.

25. MWI. 2016b. National Water Strategy 2016-2025. Ministry of Water and Irrigation (MWI), Amman, Jordan.
26. MWI. 2017. Jordan Water Sector Facts \& Figures 2017. Ministry of Water and Irrigation (MWI), Amman, Jordan.

27. Norton-Brandão, D., Scherrenberg, S.M., van Lier, J.B. 2013. Reclamation of used urban waters for irrigation purposes - A review of treatment technologies. Journal of Environmental Management, 122, 85-98. DOI:https://doi.org/10.1016/j. jenvman.2013.03.012

28. Pesce, S.F. and Wunderlin, D.A. 2000. Use of water quality indices to verify the impact of Cordoba City (Argentina) on Suquia River. Water Resour, 34(11), 2915-2926.

29. Şener, Ş., Şener, E., Ayşen Davraz. 2017. Evaluation of water quality usingwater quality index (WQI)method and GIS in Aksu River (SW-Turkey). Science of the Total Environment, 585, 131-144. DOI:10.1016/j.scitotenv.2017.01.102

30. Shakir, E., Zahraw, Z., \& Al-obaidy, A.H.M.J. 2017. Environmental and health risks associated with reuse of wastewater for irrigation. Egyptian Journal of Petroleum, 26(1), 95-102. DOI:10.1016/j. ejpe.2016.01.003

31. Sutadian, A.D., Muttil, N., Yilmaz, A.G., Perera, B.J.C. 2016. Development of river water quality indices - a review. Environmental Monitoring and Assessment, 188(1), 58. DOI:10.1007/ s10661-015-5050-0

32. Ulimat, A. 2012. Wastewater production, treatment, and use in Jordan. In: Second Regional Workshop: Safe Use of Wastewater in Agriculture. New Delhi, India, 16-18 May.

33. UN-Water. 2015. Water for a sustainable world. UNESCO.

34. WAJ. 2013. Agreements with farmers for purposes of reusing treated wastewater in irrigation. Water Authority of Jordan (WAJ), Amman, Jordan: Water Reuse and Environment Unit. 